hypersplenism. ${ }^{10}$ Based on these observations we have tried to hypothesize the sudden precipitation of CML, postsplenectomy in our case.

\section{Our Hypothesis:}

Presence of hypersplenism (In EHPVO + latent CML)

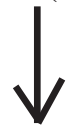

Peripheral blood counts remain normal

(In presence of proliferating marrow)

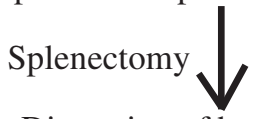

Disruption of hypersplenism

Proliferating bone marrow cells cause peripheral blood spill

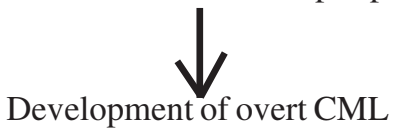

In conclusion, latent MPDs are an important cause of EHPVO and should be kept in mind whilst dealing with such patients. Patients with normal CBC in the presence of hypersplenism should be evaluated for MPD. Post splenectomy platelet counts should be closely monitored even after discharge and antiplatelet therapy continued till counts normalise. In cases of post splenectomybasophilia and absolute neutrophilia, the patient should be kept under close followup.

PRIYANKA SAXENA ${ }^{1}$, CHHAGAN BIHARI ${ }^{1}$, ARCHANA RASTOGI ${ }^{2}$, SHIV KUMAR SARIN ${ }^{3}$

Correspondence: Dr. Priyanka Saxena Department of Hematopathology ${ }^{l}$, Hepatopathlogy $y^{2}$, Hepatology $y^{3}$ Institute of Liver and Biliary Sciences D-1, Vasant Kunj, New Delhi-110070, India Email:docpriya06@ rediffmail.com

\section{References}

1. Sarin SK, Agarwal SR. Extrahepatic portal venous obstruction. Semin Liver Dis. 2002;22:43-58.

2. Denninger M H, Helley D, Valla D, Guillin MC. Prospective evaluation of the prevalence of factor $\mathrm{V}$ Leiden mutation in portal or hepatic vein thrombosis. ThrombHaemost. 1997;78:1297-8.

3. Valla D, Casadevall N, Huisse MG, Tulliez M, Grange JD, Muller
$\mathrm{O}$, et al. Myeloproliferative disorders in portal vein thrombosis in adults. Gastroenterology. 1988;94:1063-9.

4. Shallaly G, Karrar HK, Doumi A. Blood changes after splenectomy in portal hypertension. The 'Amna Model'. Sudan JMS. 2013;8:47-56.

5. Mc Bride JA, DacieV, Shapley R. The effect of splenectomy on leucocyte count. Brit J Haemat. 1968;14:225-31.

6. Sarin SK, Sollano JD, Chawla YK, Amarapurkar D, Hamid S, Hashizume M, et al. Consensus on extra-hepatic portal veinobstruction. Liver International. 2006;26:512-9.

7. Primignani M, Barosi G, Bergamaschi G, Gianelli U, Fabris F, Reati R, et al. Role of the JAK2 mutation in the diagnosis of chronic myeloproliferative disorders in splanchnic vein thrombosis. Hepatology. 2006;44:1528-34.

8. SakakuraM ,Ohishi K, Nomura K, Katayama N, Nishii K, Masuya M, et al. Case of chronic-phase chronic myelogenous leukemia with an abdominal hematopoietic tumor of leukemicclone origin. Am J Hematol. 2004;77:167-70.

9. Kim CH. Homeostatic and pathogenic extramedullary hematopoiesis. J Blood Med. 2010;1:13-9.

10. Janssen H, Leebeek F. JAK2 mutation: The best diagnostic tool for myeloproliferative disease in splanchnic vein thrombosis? Hepatology. 2006;46:1391-3.

\section{Abdominal Cocoon: An enigma}

\section{Introduction}

Abdominal cocoon or Sclerosing Encapsulating Peritonitis is due to thick fibrotic peritoneum encasing the small bowel in a small volume. The exact etiology of this type of intestinal obstruction is often unclear. Abdominal cocoon is rarely seen in male patients and we report one such case.

\section{Case report}

A 55 year old male lorry driver presented with abdominal pain and distension along with vomiting since 6 months. In addition, the patient had history of progressive anorexia and weight loss (up to $10 \mathrm{~kg}$ ). Abdominal X-ray report revealed the presence of few dilated bowel loops (air filled bowel loops) and had no free air. A computed tomography (CT) was done and reported the presence of intra abdominal cocoon encasing the small bowel loops. Laporotomy and adhesiolysis showed multiple small bowel interloop adhesions, all bowels were covered with peritoneal layer and liver was found adherent to anterior abdominal wall. (Figure 1). 

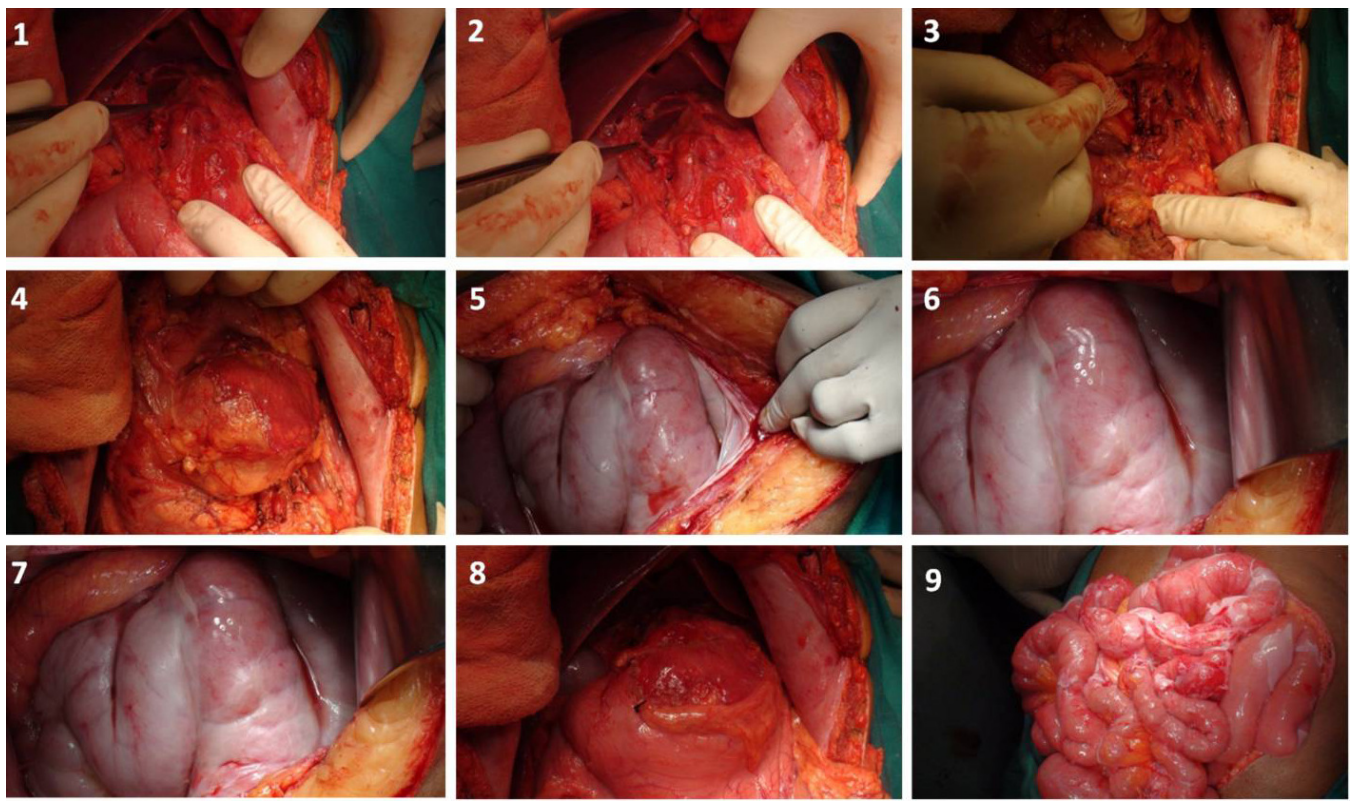

Figure 1: Operative findings: Clustered small bowel loops encapsulated within a thick membrane (peritoneum) lying adherent to the anterior abdominal wall.

\section{Discussion}

Abdominal Cocoon Syndrome (ACS) or Sclerosing Encapsulating Peritonitis is a rare cause of intestinal obstruction characterized by fibrotic encapsulation of the bowel forming a sac or cocoon along with some intestinal adhesions. The encasing membrane is an opaque fibrous structure which is not covered by mesothelium. It was first described by Owtschinnikow (1907) as peritonitis chronic fibrosa encapsulate and termed as abdominal cocoon by Foo et al. (1978). ${ }^{1}$ The exact etiology of ACS is obscure, but can be classified as primary (idiopathic) type and acquired (secondary) type. Acquired type is more common than primary type. Primary or Idiopathic form was found in adolescent girls from tropical or subtropical countries. Early menstruation and primary peritonitis caused by retrograde menstruation, superimposed with viral infection may be the most important etiological factors in this type. ${ }^{2}$ Rarely idiopathic cocoon has been described in males and an infective etiology has been suggested to account for this. Whereas prolonged â-blocker therapy (Practolol), local irritation of the peritoneum by trauma or surgical operation, intraperitoneal medical therapy (sterilizing chemicals like povidone, chemotherapeutic agents), peritoneal dialysis, peritoneal venous shunting, V-P shunts and infectious peritonitis, sarcoidosis, SLE, propranolol therapy for constrictive pericarditis, fibroid uterus, ovarian tumour and endometriosis are the major causes of secondary form which may predispose patients to peritoneal irritation subsequently inflammation that finally leads to peritoneal fibrogenesis. ${ }^{2}$ Kaushik et al. reported 6 cases of abdominal cocoon due to tuberculosis where the diagnosis was made during surgery. ${ }^{3}$ These cases presented with acute internal obstruction and caseating epitheloid cell granulomas was demonstrated in the membrane, although AFB bacilli could not be demonstrated.

$$
\begin{array}{r}
\text { MD. AEJAZ HABEEB }{ }^{1}, \\
\text { SANDEEP K VISHWAKARMA }^{1}, \\
\text { MOHD. ABDUL WAJID } \\
\text { MINASH BARDIA }^{1}, \\
\text { AVINASH } \\
\text { ALEEM A KHAN }{ }^{1}, \\
\text { N. BHEERAPPA }
\end{array}
$$

Correspondence: Dr. Md. Aejaz Habeeb Centre for Liver Research and Diagnostics ${ }^{l}$, Deccan College of Medical Sciences, Kanchanbagh, and Nizams Institute of Medical Sciences (NIMS)2, Hyderabad-500082, Andhra Pradesh, India Email:aleemakhan@rediffmail.com

\section{References}

1. Foo KT, Ng KC, Rauff A, Foong WC, Sinniah R. Unusual small intestinal obstruction in girls: The abdominal cocoon. Br J Surg. 1978; 65:427-30.

2. Sieck JO, Cowgill R, Larkworthy W. Peritoneal encapsulation and abdominal cocoon: Case reports and a review of the literature. Gastroenterol. 1983; 84:1597-601.

3. Kaushik R, Punia RPS, Mohan H, Attri AK. Tuberculosis abdominal cocoon- a report of 6 cases and review of the literature. W J Emerg Surg. 2006;1:18. 